\title{
The Scientific Miracles of Olive (Zaitūn) in the Qur'an: Perspectives of Classic and Scientific Interpretations
}

\author{
Ahmad Atabik \\ Institut Agama Islam Negeri (IAIN) Kudus, Indonesia \\ ahmad.atabik@iainkudus.ac.id
}

DOI: $10.29240 /$ alquds.v5i2.2680

Submitted: 2021-04-08 | Revised: 2021-08-07 | Accepted: 2021-09-07

\begin{abstract}
Today, commentators use scientific interpretation to investigate various types of knowledge presented by the Qur'an, such as some modern commentators combine scientific studies of fruits cited in the Qur'an with their medicinal properties, such as olives (Olea Europea). According to Al-Baqi, there are at least 7 (seven) verses that mention 'Zaitūn' (olives), which are spread across seven different letters. The purpose of this article is to dissect the anatomy of classical and scientific interpretations of the olive fruit in the Qur'an. In the scope of library research, this study employed a thematic method that refers to the literature on commentary books, scientific miracles books of the Qur'an about fruits, and articles in reputable journals. According to the findings of this study, olives are known as the name of a blessed fruit that has advantages over other fruits in several interpretations of the Qur'an. There are various interpretations of the word 'Zaitūn'; some argue that it refers to the location where many figs and olives grow, namely Jerusalem, where Prophet Isa was born and received revelation. Whereas, scientific interpretation reveals that olives are effective as herbal medicines capable of treating a variety of diseases such as treating the digestive tract in general (particularly the liver), lowering the risk of high blood pressure, treating joint problems in both hands, and lowering the risk of cancer.
\end{abstract}

Keywords: scientific miracles; olives; classic interpretations; scientific interpretations

\section{Introduction}

The Qur'an which was revealed in the past 14 centuries does not solely talk about tawhid (theology), sharia (Islamic law) and da'wah (call for converting to Islam), but also signs of Allah, the Almighty God's power through scientific data that He himself describes on earth, in sky and in this entire universe. In terms of sălih likulli zamàn wa makēn, the Qur'an is not only aimed to Arab society during the time of Prophet Muhammad, but also covering the entire human race 
throughout this era, including contemporary modern era society with scientific and technological civilization.

As modern scientific inventions of the 20th century come to appear, there is a change in the way modern Muslims view in understanding the verses of Qur'an. Modern scholars of Qur'an Science argue that the verses of Qur'an can be studied through modern scientific approaches. The growing awareness to understand the Qur'an with modern scientific approaches can increasingly open the horizon of Muslim knowledge in this modern era. Therefore, the Qur'an should be understood through scientific approaches ${ }^{1}$. The effort made is to construct a logical thinking of the cosmos (kawniyah) verses and correlate them with knowledge and medical science.

Some contemporary interpreters of the Qur'an then made an attempt to integrate the scientific study of plants and fruits mentioned in the Qur'an with its medical fields. Of the plants and fruits mostly mentioned in the Qur'an is Olives (Zaitün). Al-Baqi notes that there are at least 7 (seven) verses talking about Olives spread in seven different chapters. One of whichis even made by Allah as an object of oath (qasam) ${ }^{2}$. Experts in the Qur'an science believe that the fruit referred to by the Qur'anand even used as an object of oath must surely have special features compared to other fruits which are not mentioned.

The distinctive Olives were also conveyed by Prophet Muhammad. He once encouraged his people to use the Olives, saying, "Eat the Olives and use them as oil" (hadith narrated by Ahmad and al-Tirmizì). Based on the eminenece mentioned by the Qur'an and based on the hadith, Islamic scholars later believed that Olive was one of the medical scientific miracles. This is also strengthened by a number of modern medical studies which confirm that olive oil when applied to skin has an important role in preventing skin cancer due to sun exposure ${ }^{3}$.

Responding to the Prophet's advice, the Prophet's companions used to work under the hot sun in the desert for a long time by rubbing olive oil on their skin. Herein lies the medical wisdom of olive oil to prevent skin diseases. Moreover, many other studies talk about the benefits of olives from medical sides, such as olive oil can reduce harmful cholesterol levels ${ }^{4}$. Other studies also claim that olive oil can also reduce high blood pressures. Ripe olives can also be used

\footnotetext{
${ }^{1}$ Muchlis Hanafi, Tafsir Ilmi: Eksistensi Kebidupan Di Alam Semesta (Jakarta: Lajnah Penatashihan Mushaf Al-Qur'an Kementerian Agama RI, 2015), xviii.

${ }^{2}$ Mohammad Fuad Abd Al-Bāqī, Mu'jam Al-Mufahras Li Alfāz. Al-Qur'ān (Cairo: Dar alKutub al-Misriyyah, 1996), 334.

${ }^{3}$ Yusuf al-Haji Ahmad, Mawsü'ah Al-I'jāz, Al-Ilmì Fì Al-Qurān Al-Karim Wa Al-Sunnah AlMujahharah (Damascus: Maktabah Ibnu el-Hajar, 2003), 356.

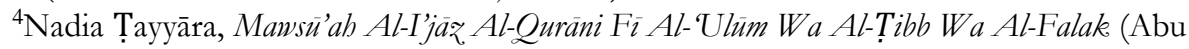
Dabi: Maktabah Al-Shafa, 2009), 453.
} 
as coloring subtances ${ }^{5}$. And of course, many other benefits of olive oil based on the study of the scientific miracles of Olives in the Qur'an which will be presented in this article. This study used a thematic method. Since this belongs to library research, referring to book literatures; so the referencesused were books of scientific miracles of the Qur'an about fruits and those related to olives. In addition, other referenceswere referred to the use of classical interpretation books compiled by experts in their fields.

\section{The concept of Scientific Miracles of the Qur'an and Scientific Interpretation}

\section{Scientific Miracles of the Qur'an}

Classic experts in the Qur'an miracles such as al-Baqillānī concluded that miracles of the Qur'an lie in the beauty of its language and literary aspects, the discussion about predecessors and future events, and the values behind the sharia stipulated by Allah ${ }^{6}$. In addition, the miracles can also be found from the verses talking about various scientific knowledge that has empirically been proven. These are called scientific miracles of the Qur'an ${ }^{7}$.

The discourse on scientific miracles of the Qur'an has widely been discussed by experts in classic and contemporary literatures. In classic literature, al-Ghazāli is a figure who agrees with the idea. In his monumental masterpiece, Ibya 'Ulumiddin, he quoted Ibn Mas'ud's opinion, stating that those who want to study the predecessors' and successors' knowledge are supposed to study, deepen and conduct researches on the contents of the Qur'an. Al-Ghazāli also stated that all knowledge is included in the deeds and attributes of Allah. This knowledge is not final, but it can develop globally and dynamically ${ }^{8}$.

In another work, Jawāhir al-Qur'an, he wrote a special chapter describing the branches of science coming from the Qur'an. According to him, these branches are religion, linguistics, and various world sciences. Sciences which have already existed and those which are still yet unknown to humankind must

235.

${ }^{5}$ Hishām Ṭalbah, Al-Ijjāz, Al-Ilmì Fì Al-Qur'ān Wa Al-Sunnah (Cairo: Der el-Hadis, 2011),

${ }^{6}$ Abu Bakr Muhammad Al-Baqillānī, I'jāz, Al-Qurān, Beirut: Dar Ibya'al-Ulum (Beirut: Dar al-Fikr al-Arabi, 1994), 12-14.

${ }^{7}$ Hamudah Muhammad Dawud Sanad, “Al-I'jāz Al-'Ilmī Li Al-Qur'Ān Wa Al-Sunnah: Nazariyah Wa Al-Tațbīq," Kulliyat Al-Dirasat Al-Islamiyyah Wa Al-Arabiyah, Dubai Uni Emirat Arab 9 (1995): 83-114. 276.

${ }^{8}$ Abu Hamid Al-Ghazālī, Ihyā' Ulümiddìn, Vol. 1 (Cairo: Maktabah al-Taufiqiyah, 2000), 
persistently be studied ${ }^{9}$. Obviously, sciences found in the Qur'an require humans to study and investigate ${ }^{10}$. Within this scope, the Qur'an serves as a guide, leading to the power of mind which guides people to remain in obedience. The Qur'an with the contents of various sciences is a miracle that must be explored with high intelligence and thoughts ${ }^{11}$.

In classic literature, al-Suyuthi in his work, al-Itqän fì'Ulüm al-Qur'än, stated that the Qur'an serves as a budan (guide) for humans endowed with the power of thinking to study the Qur'an which talks about various sciences ${ }^{12}$ including linguistics, medicine, technology, astronomy, biology, natural sciences and many others. He categorized various verses into the field of industrialization, such as iron industry, "Bring me blocks of iron?" (QC. Al-Kahfi: 96), wood and shipping industry, "And build the Arke under Our "watchful" Eyes and directions" (QC Hud: 37), building materials industry, "So bake bricks out of clay for me, O Hamân" (QC alQasas: 38), and so on ${ }^{13}$.

Whereas in contemporary literature, Zaglūl al-Naggār, Abd al-Daim Kaheel, and Nadia Țayyāra are experts who have theoretically and practically conducted researches and written many works on scientific miracles of the Qur'an. Zaglul al-Naggār is a famous figure in the scientific inimitability (i'jāz) of the Qur'an. He investigated and wrote about scientific miracles in the verses of the Qur'an. He wrote more than 150 articles and 50 books covering various scientific studies, including science of the Qur'an, i'jär, ilmiz, Islamic scientific science, science in hadith, and many others ${ }^{14}$. These works has declared him as an expert in Islamic science and scientific miracles of the Qur'an in this modern century.

In explaining this scientific miracle dimension, Zaglul revealed a lot of amazing and accurate information about the nature of universe and its phenomena which applied science had not arrived yet, except after centuries the Qur'an was revealed. This is a powerful evidence for scientific experts today that the Qur'an is truly the words of Allah calling for mankind since it was first

\footnotetext{
${ }^{9}$ Abu Hamid Al-Ghazālī, Jawāhir Al-Qur'ān (Cairo: maktabah al Wahbah, 2003), 217.

${ }^{10} \mathrm{Ahmad}$ Al-Shirbașī, Qișșat Al-Tafsìr (Cairo: Dar al-Qalam, 1962), 125.

${ }^{11}$ Nasaruddin Umar, "Al-Qur'an Abadi Sepanjang Zaman," in Ensiklopedi Kemukjizatan Ilmiah Dalam Al-Qur'an Dan Sunnah (PT Kharisma Ilmu, 2008).

${ }^{12}$ Jalāluddīn Al-Suyūṭī, Al-Itqān Fi Ulum Al-Qur'an, Vol. 2, vol. 2 (Beirut: Dar al-Kutub al-Ilmiah, 1996), 1908-27.

${ }^{13}$ Yusuf Al-Qaraḍāwī, Kaifa Nata'āmal Ma'a Al-Qur'ān Al-Aẓim (Cairo: Dar al-Shuruq, 1999), 416.

${ }^{14}$ Zaglul Al-Naggār, Qadiyyāt Al-Ijā̃z. Al-'Tlmì Li Al-Qur'ān Al-Karim Wa Dawābit AlTa'ämul Ma'ahā (Beirut: Maktabah al-Tsarwah al-Dauliyyah, 2009), 4-5.
} 
revealed to have a solid foundation ${ }^{15}$. Therefore, according to him, we are only allowed to prove scientific miracles of the Qur'an by making use of facts and laws of science which remain unchanging, despite its possibility to replenish and strengthen the essence in the future ${ }^{16}$.

A female expert in I'jāz Ilmi al-Qur'ān, Nadia Ṭayyāra, in her work entitled al-Mawsü'ah al-I'jāz al-Qur'ani fi al-'Ulüm wa al-Tibb wa al-Falak, explained that despite the fact that the Qur'an contains various kinds of sciences, it is not a scientific book as it is understood by Muslim society today. This is because the Qur'an which was revealed in the past 14 centuries contains various scientific facts. As a matter of fact, science continues to advance rapidly, but none of these scientific theories contradict to the Qur'an. In the meantime, theories which are not scientifically proven should not be compared to the words of Allah because science and technology in the future will perhaps reveal the truth and error of these theories ${ }^{17}$.

\section{Tafsìr 'IImī (Scientific Interpretation)}

In the contemporary era, there has been a new vision and type of interpretation known as tafsir ilmì(scientific interpretation). In this type, when interpreting the verses of the Qur'an, commentators use a set of contemporary sciences, such as astronomy, biology, chemistry, geology, and medicine in explaining the objectives and meanings contained therein ${ }^{18}$. In Al-Tafsir wa alMufassirun, al-Zahabi explained that scientific interpretation is an interpretation using the scientific terminology approach in narrating the verses of the Qur'an, as well as trying to explore its scientific dimensions and revealing the secrets of miracles related to the scientific information which is possiblly unknown to mankind at the time Qur'an was revealed ${ }^{19}$.

Scholars have different points of view on the existence of scientific interpretation in the verses of the Qur'an. Some accept and some refuse. Those accepting it make the Qur'an a scientific miracle, so its interpretation may use

${ }^{15}$ Zaglul Al-Naggār, Tafsìr Al-Āyāt Al-Kauniyyah Fi Al-Qur'ān Al-Karim (Cairo: Maktabah al-Syarqiyyah al-Dauliyyah, 2008), 13.

${ }^{16}$ Sujiat Zubaidi Saleh, "Epistemologi Penafsiran Ilmiah Al-Qur'an," TSAQAFAH 7, no. 1 (2011): 234.

${ }^{17}$ Ṭayyāra, Mawsū’ah Al-I'jā̃. Al-Qurāni Fì Al-Ulüm Wa Al-Ṭibb Wa Al-Falak, 8.

${ }^{18}$ Farid Abderrahman, Ijtibāed Al-Tafsìr Fì Al-Qarn Al-Räbi' 'Ashar (Jeddah: Dar Ibnu Hazim, 1986), 549.

${ }^{19}$ Muhammad Husein Al-Żahabī, Al-Tafsì Wa Al-Mufassirūn, Vol. 2 (Cairo: Maktabah Wahbah, 1995), 394. 
modern scientific theories ${ }^{20}$. This argument is also based on the fact that all sciences obtained from the Qur'an, after correctly being analyzed, will lead human-thinking to the point that all things said in the Qur'an are true and should be understood based on science development ${ }^{21}$. Of figures who accept scientific interpretation are al-Ghazālī, Fakhruddin al-Rāzī, Tantawi Jauhari, Rasyid Ridha and others.

Meanwhile, among scholars opposing this model of interpretation is alShatibi (d. 1388). In his work, al-Muwäqät, he stated that the Qur'an is not aimed at this purpose (interpretation uses a scientific theory approach) ${ }^{22}$. It means that scientific interpretation style has gone so far that the verses of the Qur'an must be confronted with scientific theories that cannot be justified for decades. The opponents also claimed that the Qur'an does not speak to humans about cosmological problems and scientific truth, rather it is a book of guidance (budan) sent down by Allah for human happiness.

Apart from these pros and cons, in reality, scientific interpretation is increasingly popular and used as a reference in investigating various sciences presented in the Qur'an nowadays. The development of scientific interpretation in the modern era was at least due to the influence of western technology and science development (Europe and the United States) on the Arab worlds and the Muslim regions, particulalry in the second half of the $19^{\text {th }}$ century when most Islamic worlds were under the rules of European countries ${ }^{23}$. The development of scientific interpretation also implies a change in the perspectives of modern Muslims on the verses of the Qur'an, notably with the emergence of modern scientific discoveries in the $20^{\text {th }}$ century.

Scientific interpretation and its relationship with modern discoveries can be exemplified in the interpretation of the word 'lamusi'un', derived from QC. alZariyat: 47, "We built the universe with "great " might, and We are certainly expanding "it".". Along with new scientific discoveries, astronomers concluded a theory which can later be said to be scientific, stating that nebulae which lies beyond the galaxy we live in continues to move away at different speeds, even celestial bodies in one galaxy are moving away from each other. This shows that the discoveries of modern science can provide new scientific meanings to the verses of the Qur'an 24.

${ }^{20}$ Imam Musbikin, Mutiara Al-Qur'an (Yogyakarta: Pustaka Pelajar, 2014), 48.

${ }^{21}$ M. Quraish Shihab, Membumikan Al-Qur'an (Bandung: Mizan, 1994), 101.

${ }^{22}$ Ibrahim bin Musa Al-Shāțibī, Al-Muwāafaqāt Fi Ushül Al-Syari'ah (Beirut: Dar al-Kutub al-'Ilmiyyah, 2013), 321.

${ }^{23}$ Johannes J G Jansen, The Interpretation of the Koran in Modern Egypt (Brill Archive, 1980), 59.

${ }^{24}$ Hanafi, Tafsir Ilmi: Eksistensi Kebidupan Di Alam Semesta, xiii. 
Various interpretations of the Qur'an verses with scientific perspectives which have been carried out do not contradict to the Qur'an along with the findings of modern sciences related to astronomy, medicine, physics, nutrition, health, zoology, botany, oceanology, and so on. Everything goes with what the Qur'an says. This is indeed the miraculous side of the Qur'an and its advantages over other samawi (heavenly) books in which they only apply to certain people, whilst the Qur'an applies to all mankind until the end of time, either at the time of Prophet Muhammad (pbuh), at present, or in the future ${ }^{25}$.

Many scientific works, both in the form of interpretations and encyclopedias, have been written by experts. The followings are several experts whose scientific interpretationworks have colored the comprehension of the Qur'anverses with scientific approaches, starting from the $14^{\text {th }}$ century to the present contemporary era: Al-Gazali with Jawähir al-Qur'ān, Fakhruddin al-Rāzì with Mafätih al-Ghaib, Muhammad Ahmad al-Ghamrawi withSunan Alläh al-

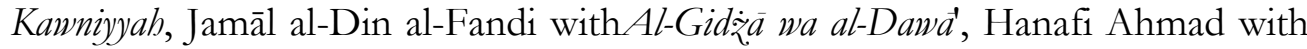
Al-Tafsir al-Ilmiy li al-Ayät al-Kawniyyah fi al-Qur'an, and Thanthawi Jauhari with AlJawāhir fi Tafsì al-Qur'änn ${ }^{26}$. Meanwhile, Nadia Țayyāra wrote encyclopedia entitled Mawsu'ah al-I'jaz al-Qur'añ fí al-'Ulüm, wa al-Tibb wa al-Falak, and Yusuf al-Haji Ahmad with Mawsü'ah al-I 'jaz al-Ilmi fi al-Qur'an al-Karim wa al-Sunnah alMutabharah.

\section{Olives in the Qur'an Interpretation Perspectives}

Many fruits are mentioned in the Qur'an, one of which is olives. Husayn al-Shafi'i in his masterpiece entitled 'al-Dalil al-Mufahras' explains that the term'olives' is mentioned in the Qur'anfor 7 times in 5 different chapters, with various derivations. Sometimes the term is referred to as 'zaitūn', 4 times found in chapter al-An'am (6): 99 and 141, chapteral-Nabl (16): 11, and in chapter al-Tin (95): 1. Another term is called as'zaitünan'for once in chapterAbasa (80): 29. Another is referred to as 'zaituba'for once in chapter al-Nür (24): 35. Lastly, it isalso referred to as 'qaitūnat' once in chapteral-Nür (24): $35^{27}$.

\footnotetext{
${ }^{25}$ Ṭayyāra, Mawsū'ah Al-I’jāz. Al-Qurāni Fì Al-Ulüm Wa Al-Ṭibb Wa Al-Falak, 10.

${ }^{26}$ Izzatul Laila, "Penafsiran Al-Qur'an Berbasis Ilmu Pengetahuan," Epistemé: Jurnal Pengembangan Ilmu Keislaman 9, no. 1 (2014): 45-66.

${ }^{27}$ Hosen Muhammed Fahmi Al-Shāfi'̄, Al-Dalīl Al-Mufahras Li Alfäz Al-Qur'ān (Cairo: Der el-Hadis, 2000), 464.
} 
Table 1, Olive Verses Interpretation

\begin{tabular}{|c|c|c|}
\hline Olive Verses & Commentators & Interpretation \\
\hline $\begin{array}{l}\text { Shura 'Abasa } \\
\text { verser } 22, \\
\text { Shura al-Nahl } \\
\text { verses } 11\end{array}$ & Al-Shawkān̄̄ & $\begin{array}{l}\text { The creation of olive tree which has many } \\
\text { benefits for human health }\end{array}$ \\
\hline \multirow[t]{3}{*}{$\begin{array}{l}\text { Shura al-Tin } \\
\text { verser } 1\end{array}$} & Al-Rāzì & $\begin{array}{l}\text { That 'zaitūn' is the name of fruit known } \\
\text { today, indicating the excess content of the } \\
\text { fruit. }\end{array}$ \\
\hline & Al-Qurțubī & That 'zaitūn' refers to al-Aqsa mosque. \\
\hline & Al-Ṭabarī & $\begin{array}{l}\text { The name of a certain type of tree or fruit } \\
\text { on the reason that the Arabs do not } \\
\text { recognize the word 'raitün' as a place, they } \\
\text { only refer'zaitün' as the name of a type of } \\
\text { tree or fruit. }\end{array}$ \\
\hline $\begin{array}{l}\text { Shura al- } \\
\text { An'ām verses } \\
99 \text { and } 141 .\end{array}$ & Ibnu Kathīr & $\begin{array}{l}\text { There is a process similarity between } 3 \\
\text { fruits -palm, olive, and pomegranate- from } \\
\text { its seed shapes, trees, and fruit colors. } \\
\text { However, it has a different taste and smell. }\end{array}$ \\
\hline \multirow[t]{2}{*}{$\begin{array}{l}\text { Shura al-Nūr } \\
\text { verses } 35\end{array}$} & Al-Shawkānī & $\begin{array}{l}\text { Olive is called a blessed tree, the fruits of } \\
\text { which can be used as oil which can be used } \\
\text { as an igniter for lamp. According to Al- } \\
\text { Shawkāni, olive tree in this verse lies in the } \\
\text { desert, which is not covered by any sun, } \\
\text { both at rising and setting time. }\end{array}$ \\
\hline & Ibnu Kathīr & $\begin{array}{l}\text { The olive tree in the Sahara field is not } \\
\text { covered by the shade of other trees, noris } \\
\text { covered by mountains, nor is it in a cave. }\end{array}$ \\
\hline
\end{tabular}

From the Qur'an verses using the term'zaitün', 3 of which talk about olive tree, such as in chapter al-An'am (6): 99 and 141. Both verses almost have similarredactions when talking about olives. In both verses, Allah talks about the creation of various trees, including palm trees, olive trees and pomegranate trees. Allahhas created those trees in different shapes, colors and flavors ${ }^{28}$. In

\footnotetext{
${ }^{28}$ Imaduddīn Ibnu Kathīr, Tafsìr Al-Qur'ān Al-'Azìm (Beirut: Dar al-Kutub al-Ilmiah, 2000), 118.
} 
chapter'Abasa verse 29, Allah also implicitly talks about the creation of olive tree which has many benefits for human health ${ }^{29}$.

The last redaction of the term 'zaitūn' is found in chapter al-Tin (95): 1. In this verse, Allah makes an oath by the words'al-Tin' and 'al-zaitün'. Al-Razi explains that interpreters are in a debate over the meaning of the word 'zaitūn'. Some argue that 'zaitūn' is the name of fruit known today, indicating the excess content of the fruit. There are also some arguing that 'zaitün'refers to a place where many figs and olives grow, that is Jerusalem, the place where Prophet Isa was born and received revelations ${ }^{30}$. Some other state that 'al-zaitün' refers to alAqsa mosque ${ }^{31}$.

Al-Ṭabarī prefers defining 'raitün' in the verse as the name of a certain type of tree or fruit on the reason that the Arabs do not recognize the word 'raitün' as a place, they only refer'zaitun' as the name of a type of tree or fruit ${ }^{32}$. Meanwhile, Al-Marāghì argues that the word ' 'aitūn' means Noah period. According to him, after some time,the large ship he was on board was about to land, Noah saw a bird carrying an olive leaf, as a sign of salvation and safety ${ }^{33}$.

Shihab argues that interpreters arguing that 'raitūn' is the name of a particular tree or fruit tend to link it with the oath made by Allah in this verse andthe fourth verse which state that man was created by Allah in the very best shape. Shihab continues, interpreters explain that when Allah made an oath by the name of a tree or fruit, the tree or fruit must have many benefits. Allah's oath in this verse is also a sign that humanbeings created by Him also have potentials to be able to give many benefits as the olive plant or fruitdoes ${ }^{34}$.

In the Qur'an,chapter Nür verse 35, olive isreferred to the word 'qaitūnat' and 'qaitub $\vec{a}$. In this verse, olive is called a blessed tree, the fruits of which can be used as oil which can be used as an igniter for lamp. According to Al-Shawkānī, olive tree in this verse lies in the desert, which is not covered by any sun, both at

\footnotetext{
${ }^{29}$ Muhammad bin Ali bin Muhammad Al-Shawkānī, Fath Al-Qadir Al-Jämi' Baina Fannai Al-Riwayah Wa Al-Dirayah Min Tlm Al-Tafsir, Vol. 4 (Beirut: Dar Ibnu Hazim, 2014), 457.

${ }^{30}$ Fakhruddin Al-Rāzī, Al-Tafsìr Al-Kabìr Aw Mafätỉ Al-Gayb, Vol. VIII (Cairo: Der elHadis, 2012), 233.

${ }^{31}$ Muhammad ibn Ahmad Al-Qurthubi, Tafsìr Al-Qurthubi, Vol. 9 (Beirut: Dar al-Kutub al-'Ilmiyah, 2014), 547.

${ }^{32}$ Ibnu Jarir Al-Ṭabarī, Jàmi' Al-Bayān Fi Ta'mūl Ay Al-Qur'àn, Vol. 12 (Beirut: Dar alKutub al-Ilmiyah, 2009), 631.

${ }^{33}$ Mustafa Al-Marāghī, Tafsìr Al-Tafsìr Al-Marāghì, Vol. 8 (Beirut: Darul Fikir, 2002), 193.

${ }^{34}$ M. Quraish Shihab, Tafsir Al-Misbab: Pesan, Kesan, Dan Keserasian Al-Qur'an, Vol. 15 (Jakarta: Lentera Hati, 2005), 375.
} 
rising and setting time ${ }^{35}$. Olive oil produced from the tree is the best. The notion of olive tree as a blessed tree is also mentioned in chapter al-Mukminün (23): 20.

Ibn Kathir described the word 'zaitunab'as the olive tree that does not growin the eastern part. As a result, the morning sunlight cannot reach it, nor does it grow in the western part, as a result of which, there is a part not exposed to the sunlight when itpenetrates towards the west. However, it grows in the middle area which is always exposed to the sunlight from the morning to evening, so that the oil it produces is clear, good and shiny. Ibn Kathir also quoted Ibn Abbas's interpretation, that the olive tree in the Sahara field is not covered by the shade of other trees, noris covered by mountains, nor is it in a cave. In short, the tree is covered by nothing. That is why this kind of tree produces the best oil ${ }^{36}$.

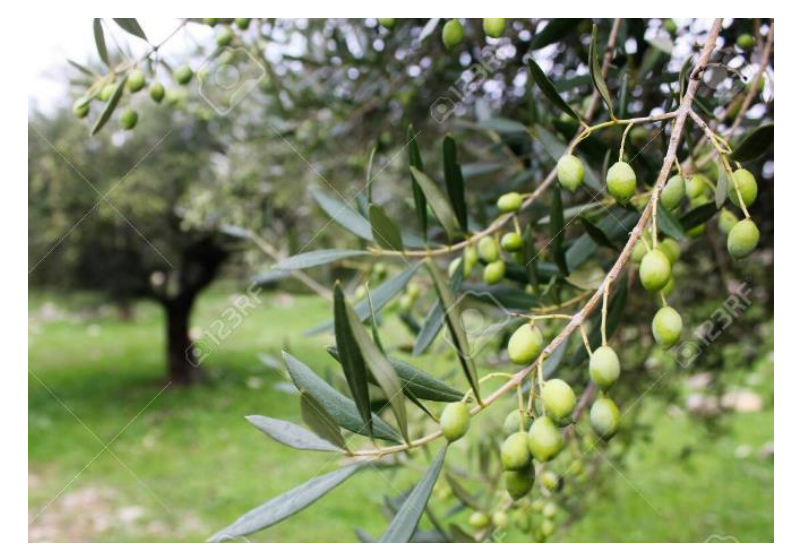

Pic 1, Olive tree

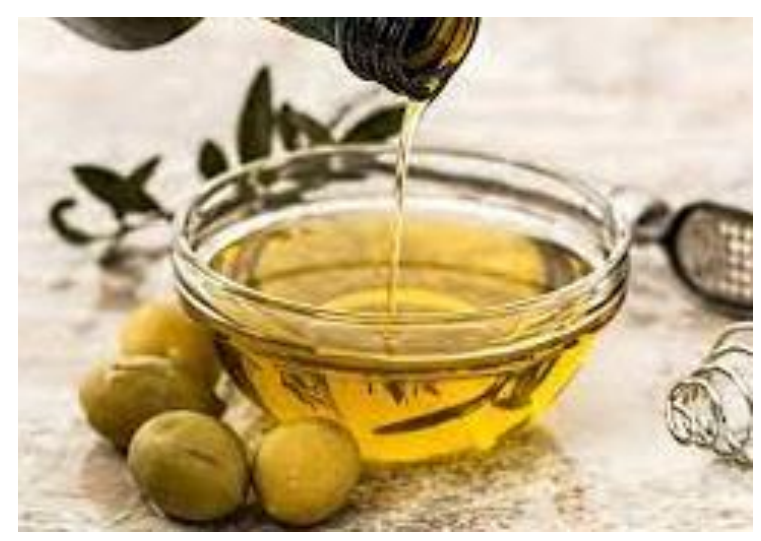

Pic 2, Olive oil

\footnotetext{
${ }^{35}$ Muhammad bin Ali bin Muhammad Al-Shawkānī, Fath Al-Qadìr Al-Jāmi’ Baina Fannay Al-Riwāyah Wa Al-Dirāyah Min Tlm Al-Tafsìr, Vol. 3 (Beirut: Dar Ibnu Hazim, 2014), 439.

${ }^{36}$ (Kathīr, 2000, p. 347)
} 


\section{Olive, a Blessed Tree}

In the scientific world, olive tree has a scientific name called 'olea europea'which is still classified intooleaceae family. Olive is a tree called by the Qur'an (chapteral-Mu'minün verse 20) as a blessed tree. This tree is called by archaeologists as the oldest tree in the world. In Palestine, a 2.000-year-old olive treewas once found. The information was obtained from archeological sources showing that olives were found around 5,000-3,000 BC. Olives can be found in the Arabian Peninsula and Mediterranean countries such as Egypt, Tunisia, Libya, Algeria, Morocco, Turkey, Italy, Greece, Spain, Portugal, as well as California State in America, Mexico, Peru and Southern Australia and some Asian countries 37.

In Prophet Noah's story, when he was about to land from the ship after Allah had sent a terrible flash flood to his unbelievers, he got news from a birdwhich was sent over to find information on land which was no longer inundated. The bird gave information by carrying a leaf from an olive tree. Noah was very glad; Allah had allowed himself and his followers to prosper the earth again. From this story, it is known that at that time, olive trees were already available there ${ }^{38}$. Al-Qurtubi explains, this olive tree was the first tree to grow on earth, first to grow back after the Noah flood, grew in the houses of the Prophets and a number of holy places. This tree was even prayed for by the blessings of 70 Prophets $^{39}$.

This olive tree seems special because the whole parts of the tree can provide benefits to mankind. From its wooden trunks, tall buildings can be built and pulpit poles stand upheld. From its leaves, a crown can be made for the champion in a sport event. Its branches can be used as a sign of peace, kindness and loyalty; its fruits can be used as a food flavoring. Oil taken from olive juice can be used as a materialto turn the lights on. Its fruits and oil can also be used as medicine for various types of diseases ${ }^{40}$.

456.

${ }^{37}$ Ahmad, Mawsü'ah Al-I'jär. Al-Ilmì Fì Al-Qurān Al-Karìm Wa Al-Sunnab Al-Mujabharah, 2010), 438.

${ }^{38}$ Mubashir \& Mahran, Ghà̃ā' Wa Al-Dawā' Fì Al-Qur'ān Al-Karìm (Cairo: Der el-Fikr,

${ }^{39}$ Muhammad ibn Ahmad Al-Qurțubī, Tafsìr Al-Qurțubī, Vol. 3 (Beirut: Dar al-Kutub alIlmiah, 2014), 322.

${ }^{40}$ Mubashir \& Mahran, Ghà̃ä’'Wa Al-Dawä̀' Fì Al-Qur'ān Al-Karim, 439. 
Olea europaea is a shrub which can last for a long time. According to Johnson, the classification of olive plants is as follows: Kingdom: Plantae, Sub Kingdom: Tracheobionata, Super Divisio: Spermatophyta, Divi Asio: Magnoliophyta, Class: Magnoliopsida, Sub Class: Asteridae, Family: Oleaceae, Genus: Olea, Species: Olea europaea ${ }^{41}$. Al-Naggār asserts that olive tree family includes 28 species and there are about 500-600 types of flower plants spread in the whole wide world in cold and cool regions, also spread in special areas. Most are in the Mediterranean regions, and in the southwest of Asian continent. Although this tree is widespread, it belongs toa rare tree species because it is a strong tree in an area 42 .

Olive tree is a tree with a long lifespan of more than a hundred or even thousands of years. Olea europaea plant reaches 3-15 meters in height. This plantcontinuously produces fruits without human labor assistance, as it will always look beautiful to be seen ${ }^{43}$. Olive tree keeps going green and its leaves live for 3 years, before new leaves appear. At the end of spring, olive tree will bloom in the shape of a bunch of 10 to 40 flowers in each group. However, only 1 out of 20 flowers will turn to olives ${ }^{4}$.

In the next phase, Olive treeis usually blooming between June and October. Olive oil can be of good quality after 6-8 months of blooming period. At that time, it turns to black, indicating that it is fully ripe. In terms of harvestingtime, it usually starts from September to March of the following year. The wood of olive tree has a beautiful golden brown color. Moreover, Romans pay an honor to olive tree wood by strictly having it forbidden to be used as fire woods ${ }^{45}$.

Olive flowers are small in size, white or beige in color, with about 6.10 $\mathrm{mm}$ in length. Flowers bloom in October to March. Ovoid olives, which are small in size, light green with white patches and turning dark purple when ripe, with 10 $\mathrm{mm}$ in diameter, are sharp in shape ${ }^{46}$. Olive ripeness is determined by its color. Olives with green color are not fully ripe yet. Meanwhile, black olives indicate fully ripe. Both of these olives (ripe or almost ripe) are usually consumed as food flavoring. Ripe olives can be used to make oil by squeezing ${ }^{47}$. Olives contain various vitamins and nutrients, but are usually not eaten directly (before processed) due to their metallic flavors.

${ }^{41}$ J.M Johnson, Fructose. InEncyclopedia of Food Science, Food Technology and Nutrition, ed. R. Macrae, R. K. Robinson, and M. Sadler. (London: Academic Press Ltd, 1993), 405.

${ }^{42}$ Al-Naggār, Tafsìr Al-Ayyät Al-Kauniyyah Fi Al-Qur'ān Al-Karim, 314.

${ }^{43}$ Shihab, Tafsir Al-Misbab: Pesan, Kesan, Dan Keserasian Al-Qur'an, Vol. 15.

${ }^{44}$ Al-Naggār, Tafsìr Al-Āyàt Al-Kauniyyah Fi Al-Qur'ān Al-Karim, 316.

${ }^{45}$ Mubashir \& Mahran, Ghà̃à' Wa Al-Dawà' Fì Al-Qur'ān Al-Karim, 432.

${ }^{46}$ Johnson, Fructose. InEncyclopedia of Food Science, Food Technology and Nutrition.

${ }^{47}$ Mubashir \& Mahran, Ghà̃à' Wa Al-Dawà' Fì Al-Qur'ān Al-Karìm, 453. 
Not only can the fruitsbe taken advantage, but also the leaves. The leaves of olive tree contain substances which are beneficial for the human body and in some cases, they can treat a number of diseases, such as high blood pressure, high cholesterol, and prevent cancers and treat various diseases caused by viruses. More specifically, olive leaves can treat joint diseases, rheumatic, and diseases on hair, nails, skin and teeth ${ }^{48}$. Another benefit of olive leaves is that they can be used as a media to clear up wounds by ancient Jewish society. In addition, olive leaves also contain anti-microbial substances and are very effective in exterminating a number of fungi, viruses and bacteria.

Table 2, Olive Efficacy ${ }^{49}$

\begin{tabular}{|c|c|c|}
\hline Types of Olive & How to Use & Medical Benefits \\
\hline Olive Oil & Smeared on pores & $\begin{array}{lll}\text { Preventing any substances } & \text { from } \\
\text { passing through it } & & \end{array}$ \\
\hline \multirow{2}{*}{ Olive Oil } & Smeared on hair & Making hair beautiful and long \\
\hline & Smeared on skin & Treating measles \\
\hline & \multirow{5}{*}{$\begin{array}{l}\text { Potion (as a } \\
\text { drink) }\end{array}$} & Serving as an antitoxin \\
\hline & & $\begin{array}{l}\text { Rejuvenating digestive organs, } \\
\text { particularly liver }\end{array}$ \\
\hline Olive Oil & & $\begin{array}{l}\text { Reducing blood pressure, cholesterol } \\
\text { absorption in the body and } \\
\text { cholesterol circulation in the blood }\end{array}$ \\
\hline \multirow[t]{2}{*}{ Olive Oil } & & $\begin{array}{l}\text { Treating rheumatoid arthritis. This } \\
\text { type of inflammatory disease attacks } \\
\text { the joints of hands, feet and others }\end{array}$ \\
\hline & & $\begin{array}{l}\text { preventing other cancers, such as } \\
\text { colon cancer, uterine cancer, and } \\
\text { ovarian cancer }\end{array}$ \\
\hline
\end{tabular}

${ }^{48}$ Ṭayyāra, Mawsū'ah Al-I'jāz. Al-Qurāni Fì Al-Ulüm Wa Al-Tỉbb Wa Al-Falak, 456.

${ }^{49}$ A Kiritsakis and P Markakis, "Olive Oil: A Review," Advances in Food Research 31 (1988): 453-82. 


\begin{tabular}{|lll|}
\hline Olive Oil & Mixed food & $\begin{array}{l}\text { Making food more delicious and } \\
\text { nutritious }\end{array}$ \\
\hline Olives & $\begin{array}{l}\text { Cooked, } \\
\text { processed } \\
\text { eaten }\end{array}$ & $\begin{array}{l}\text { Making food more nutritious and } \\
\text { increasing appetite }\end{array}$ \\
& &
\end{tabular}

\section{Olives in Modern Herbal Medicine: Scientific Interpretation}

Olive is a tree blessed by Allahwith many features. In the Qur'an,chapteral-Mukmin verse 20, Allah says: " ... and also a tree which grows on Mount Sinai which produces oil and relish as a food for those who like to eat it." According to interpreters, the tree referred to in the above verse isolive tree. Of which fruits can be used for oil and food for its consumers ${ }^{50}$. Whereas, the mention of Mount Sinai as a place wherethe olive tree grows, they suggest that this tree first grew and spread on the Mount Sinai ${ }^{51}$. On that basis, experts of scientific interpretation believe that this verse contains scientific miracleaspects from olives.

In addition to the verseabove, the scientific miracle of olive oil is also revealed by the Qur'anin chapter al-Nürverse 35, "... lit from 'the oil of a blessed olive tree, "located' neither to the east nor the west, whose oil would almost glow, even without being touched by fire." Experts of scientific interpretation assert that this verse contains scientific miracle of olive oil. Also, its scientific miracle was conveyed by Prophet Muhammad in his saying, "Eat olives and use them as oil, because they grow from a blessed tree" (Hadith narrated by Ahmad and al-Tirmizi). With this scientific miracle, experts believe that olive oil has many benefits for human life, whether consumed for food flavoring or used as medicine.

In traditional treatment, Ibn Qayyim (w. 1350) in the book entitled Zād al$M a^{\prime} a d$ explains that olive oil can be used to cover pores of the body and prevent substances passing through the pores. If used after having a warm bath, olive oil will repair and moisturize the body. If used as hair oil, it will make your hair beautiful and long. Olive oil is also efficacious for treating measles and various other diseases. Besides, based on the quality of oil, Ibn Qayyim explains that the olive oil quality depends on the quality of the olives. The juice from the ripe fruits

\footnotetext{
${ }^{50}$ Al-Shawkānī, Fatḥ Al-Qadìr Al-Jāmi’ Baina Fannay Al-Riwāyah Wa Al-Dirāyah Min 'Im Al-Tafsir, Vol. 3, 325.

${ }^{51}$ Fakhruddin Al-Rāzī, Al-Tafsìr Al-Kabìr Aw Mafatih Al-Gayb, Vol. VIII (Cairo: Dar alHadis, 2012), 45.
} 
is the best. Oil from olives is still cold and dry in nature. Oil from red olives has medium quality and that from black olives isbalanced as hot and moist in nature ${ }^{52}$.

Olive oil comes from olives which have been ripe by extracting them into vegetable oil, which can reach $60-70 \%$ of a medium sized fruit. Olive oil is composed of a number of very important chemical compounds, that is, of glycerin and fatty acids (glycerides). Fatty acids are great in number found in olive oil content ${ }^{53}$. Olive oil varies according to its colors, flavors and places whereit grows. There is onewithgolden and dark green color. There is one with sharp and soft flavor. To get a liter of olive oil, five kilograms of its fruits is needed to be extracted or squeezed. Olive oil is the only oil which can be drunk directly or consumed after being extracted. Olive oil produced from black olives is the best type and works well as an antitoxin ${ }^{54}$.

Some of the latest methods used to extract olive oil are carried out by repeated filtration. This method is not very good because it can eliminate the oil content which actually makes the body healthy. Olive oil should not be heated on fire until boiling since it can actually turn into a poison. The oil extracted at normal temperatures is actually able to withstand heat as high as 270 degrees Celsius. Olive oil is often processed first with soda before it is fermented to remove the bitter flavor. This method can eliminate polyphenols which are actually useful for the body ${ }^{55}$.

In terms of health, recent studies prove that olive oil is beneficial for digestion tool in general, especially for liver. Olive oil also has a better quality than other oils, either vegetable or animal oils, because it has no effect which can cause diseases in the blood circulation and arteries such as those found in other types of oils ${ }^{56}$. It is said that olive oil contains botasium, calcium, magnesium, phosphorus, iron, copper, sulphur and others, with additional compositions of compounds reaching 1000 compositions, and inside of it are several chemical compounds, all of which are very beneficial for the human body and some are

${ }^{52}$ Ibnu Qayyim al- Jauziyah, Zad Al-Ma'ad Fi Hady Khair Al-Ibad (Beirut: Muassasat alRisalat, 2009), 708. Ma'abā, 143.

${ }^{53}$ Al-Naggār, Qadìyyāt Al-I'jā̀, Al-'Imì Li Al-Qur'ān Al-Karim Wa Dawābit Al-Ta'àmul

${ }^{54}$ Ahmad, Mawsü'ah Al-I'jäz. Al-Ilmì Fì Al-Qurān Al-Karim Wa Al-Sunnah Al-Mujabharah, 469.

${ }^{55}$ Ṭayyāra, Mawsū'ah Al-I'jāz, Al-Qurāni Fì Al-Ulüm Wa Al-Tibb Wa Al-Falak, 457.

${ }^{56}$ Ṭayyāra, Mawsü'ah Al-I’jàz, Al-Qurāni Fī Al-Ulüm Wa Al-Tíbb Wa Al-Falak. 
very important for health. And from here, we know that the eminence of olive oil or fatty acids, and vegetable oils are best sourced from olive oil ${ }^{57}$.

Olive oil is also efficacious to reduce blood pressure, cholesterol absorption in the body, cholesterolcirculation in the blood to about $13 \%$, and bad cholesterol in the blood known as low density lipoprotein (LDL) to about $21 \%$ and to increase good cholesterol in the blood or high density lipoprotein (HDL) the body needs. This is strengthened by a study on the inhabitants of Crete Island, Greece, who are widely known as the least affected by coronary heart disease in the world. Apparently, the oil they consume the most in daily food comes from olives. Olive oil has been medically proven to be able to reduce harmful cholesterol levels and also to prevent the occurrence of blood vessel blockage and coronary heart disease. In addition, olive oil is also an antioxidant because it contains vitamin $\mathrm{E}$ and polyphenolic compounds which can prevent blood vessel blockage ${ }^{58}$.

Another benefit of olive oil is to reduce the risk of high blood pressure. This is proven by Dr. Aldo Ferrara with his study from the University of Naples, Italy published in the Archives of Internal Medicine magazine, on March 27, 2000. He examined 23 cases of people affected by high blood pressure. The lowest blood pressure among of whom was found to be at the level of 165/104 $\mathrm{mmHg}$ who took hypertension medication. Those with high tensity were divided into two groups; the first one was recommended to consumefood containing sunflower oil, while another group was recommended to consume virgin olive oil. The result of the study showed that those consuming olive oil went thorugh a decrease in blood pressure by seven points, while it did not occur to the group given sunflower oil. Patients who consume food rich in olive oil content can reduce the dose of hypertension medication they need by half, of course, under the doctor supervision $^{59}$.

Another study claims that olive oil can treat Rheumatoid Arthritis. This type of inflammatory disease attacks the joints of both hands, both legs, and others. Scientists assume that there is a contradictingcorrelation between olive oil consumption and the case of inflammatory disease. The American Journal of Clincal Nutritionmagazine on November 1999 edition published a study on 145 people with Rheumatoid Arthritis in southern Greece. They were then compared to healthy people. This study showed that consuming olive oil played a role in preventing the occurrence of Rheumatoid Arthritis. People with less olive oil consumption had

\footnotetext{
${ }^{57}$ Abdullah Abelaziz Al-Muslih; Abdjawad Al-Sāwī, Al-I'jāz, Al-Ilmì Fì Al-Qur'ān Wa AlSunnab (Jeddah: King Fahd al-Watani, 2008), 342.

${ }^{58}$ Ṭayyāra, Mawsǜah Al-I’jār. Al-Qurāni Fì Al- Ulüm Wa Al-Ṭibb Wa Al-Falak, 458.

${ }^{59} \mathrm{~L}$ Aldo Ferrara et al., "Olive Oil and Reduced Need for Antihypertensive Medications," Archives of Internal Medicine 160, no. 6 (2000): 837-42.
} 
a risk of developing inflammatory disease, compared tothose withmore olive oil consumption $^{60}$.

Many studies have uncovered that there is a strong correlation between olive oil consumption and a low average number of breast cancer cases. As revealed by Prof. Dr. Gerd Assamann, the chairperson of the Institute for Arteriosclerosis Research at the University of Münster, Germany, and one of the world's most famous Arteriosclerosis experts. A study on 2.564 women with breast cancer, the results of which were published in 1995, confirmed that there was a contradicting correlation between breast cancer and olive oil, that is, consuming olive oil is essential for self-protection and prevention from breast cancer. A number of other studies have shown that consuming olive oil can prevent other cancer attacks, such as colon cancer, cervical cancer, and ovarian cancer ${ }^{61}$.

\section{Differences between Classic and Scientific Interpretations on Olives}

In the interpretation of Olives by classic scholars, they are more likely to interpret normatively and present various differences among scholars in perceiving the word 'Zaitūn'. According to al-Razi's commentary of QC al-Tin: 1, commentators disagree on the meaning of the word 'Zaitün'. Some argue that zaitum is the name of the fruit that is known today, exemplifying the benefits of the fruit's content. Some believe that what is meant is the location where many figs and olives grow, namely Jerusalem, the location where Prophet Isa was born and received revelation. Al-Razi's commentary simply describes different perspectives on the meaning of zaitūn.

In contrast to them, scientific commentators employ auxiliary sciences to interpret the meaning of the Qur'an verses. They also link specific themes studied to various terms, theories, and scientific research findings. For example, when commenting on zaitūn, Zaglul al-Najjar reveals the elements and properties of olive oil. He asserted that olive oil is composed of a number of very significant chemical compounds, namely glycerin and fatty acids (glycerides), fatty acids in large amounts in olive oil. Ahmad also revealed the various advantages of olive oil's color changing. He stated that there's olive oil with golden and dark green in

\footnotetext{
${ }^{60}$ Athena Linos et al., "Dietary Factors in Relation to Rheumatoid Arthritis: A Role for Olive Oil and Cooked Vegetables?," The American Journal of Clinical Nutrition 70, no. 6 (1999): 107782.

${ }^{61}$ Al-Sāwī, Al-I'jà̃. Al-Ilmì Fì Al-Qur'àn Wa Al-Sunnah, 359.
} 
colors. The flavor is both sharp and soft. One liter of olive oil requires the extraction or squeezing of five kilograms of fruit.

There is also a significant difference in how classic commentators interpret the word 'Zaitūn' in QC al-Nur: 35. Despite the fact that this verse is highly scientific, some classic commentators have explained it simply, without presenting scientific principles. For instance al-Shawkany, he interprets 'Zaitūn' as 'Zaitunat' and 'Zaituba'. In this verse, 'Zaitūn' is referred to as a blessed tree, and the fruit of the tree can be used to make oil that can be used to light lamps. According to him, the olive tree in this verse is in the desert, where the sun does not rise or set. Despite being a modern-day commentator, he does not explain the benefits of olive fruit and olive oil in his commentary.

When interpreting the blessing in this olive, Al-Qurtubi is also relatively normative. He claimed that this olive tree was the first to grow on Earth, the first to grow even after Noah's flood, growing in the houses of the prophets and other holy places. This tree was even blessed by 70 Prophets who prayed for it. According to him, the blessing of olive is due to the fact that it is prayed for by a number of prophets and grows in their various places of worship.

Whereas, scientific commentators describe the blessings of olives in QC al-Nur: 35, they pay more attention to the many benefits of olives for human health. It is also supported by scientific studies. Al-Tayyara revealed the Olive blessing that its oil is beneficial to the gastrointestinal tract in general, particularly the liver. Olive oil's quality also outperforms that of other oils, both vegetable and animal oils, because it lacks the effects that can cause diseases of the circulation and arteries that are found in other types of oils. While Muslih and Sawi explained that the blessing of olives is found in the content of olive oil, which is beneficial for human physical needs due to the presence of potassium, calcium, magnesium, phosphorus, iron, copper, sulfur, and others, with addition of compound mixtures reaching 1000 compositions, and it is composed of several chemical compounds, all of which are very beneficial to the human body and some of which are considered necessary for health.

\section{Conclusions}

Modern scientific discoveries of the twentieth century changed the way modern Muslims perceived in understanding the verses of the Qur'an. Modern scholars of the Qur'an discipline argued that the verses of the Qur'an can be studied with a modern scientific approach. This interpretive approach with scientific theories is called tafsir ilmi(scientific interpretation). It is an effort to understand the verses of the Qur'an which contain scientific signs from the perspective of modern science. Also, tafsir ilmi is commentators' hard work to reveal the relationship between the cosmological verses in the Qur'an with scientific discoveries aiming to reveal scientific miracles. 
In the Qur'an, the word 'Zaitün' (Olive) has various forms, found in 7 (seven places), the commentators have different opinions; Some argue that zaitūn is the name of a fruit as it is known today, with its efficacies. In addition, some assert that zaitün is the place where many olives grow, that is Jerusalem where Prophet Isa was born and received revelation (al-Razī). Several other commentators claim that zaitūnrefers to the al-Aqsa mosque (al-Qurțubī). AlTabari states that qaitūn in the verse is the name of a type of tree or fruit popular among the Arabs (al-Tabarī). Meanwhile, al-Maragi explains that the word zaitūn means the time of Prophet Noah since at a particular time when the giant ark he was on was about to land, he saw birds carrying olive leaves, as a sign of security and safety.

In the meantime, in scientific interpretation studies, experts explain more about the benefits and efficacies of olives for herbal medicine for the human body. These benefits are sometimes generated after being extracted into olive oil, sometimes as food ingredients. Some of Olive efficacies based on scientific researches are as follows; it serves as a herbal medicine that can treat various diseases including treating the digestive organs in general (particularly liver) and arthritis in both hands, reducing the risk of high blood pressure and breast cancer. It is also effective in reducing dangerous cholesterol levels and preventing clogged arteries and coronary heart diseases.

\section{Bibliography}

Abderrahman, Farid. Ijtihād Al-Tafsìr Fì Al-Qarn Al-Räbi' 'Ashar. Jeddah: Dar Ibnu Hazim, 1986.

Ahmad, Yusuf al-Hajj. Mawsǜah Al-I'jār. Al-Imì Fì Al-Qurān Al-Karim Wa AlSunnah Al-Mujahharah. Damascus: Maktabah Ibnu el-Hajar, 2003.

Al-Bāqī, Mohammad Fuad Abd. Mu'jam Al-Mufahras Li Alfār, Al-Qur'ān. Cairo: Dar al-Kutub al-Misriyyah, 1996.

Al-Baqillān̄̄, Abu Bakr Muhammad. I'jāz, Al-Qurān. Beirut: Dar Ibya'al-Ulum. Beirut: Dar al-Fikr al-Arabi, 1994.

Al-Ghazālī, Abu Hamid. Ibyà' Ulümiddìn, Vol. 1. Cairo: Maktabah al-Taufiqiyah, 2000.

—. Jawāhir Al-Qur'ān. Cairo: maktabah al Wahbah, 2003.

Al-Marāghī, Mustafa. Tafsìr Al-Tafsìr Al-Maräghī, Vol. 8. Beirut: Darul Fikir, 2002.

Al-Naggār, Zaglul. Qadiyyāt Al-I'jäz. Al-'Ilmì Li Al-Qur'än Al-Karim Wa Dawäbit AlTa'āmul Ma'ahā. Beirut: Maktabah al-Tsarwah al-Dauliyyah, 2009. 
436 | AL QUDS : Jurnal Studi Alquran dan Hadis vol. 5, no 2, 2021

. Tafsìr Al-Āyät Al-Kauniyyah Fi Al-Qur'ān Al-Karim. Cairo: Maktabah alSyarqiyyah al-Dauliyyah, 2008.

Al-Qaraḍ̄āwī, Yusuf. Kaifa Nata’āmal Ma’a Al-Qur'ān Al-Aẓim. Cairo: Dar alShuruq, 1999.

Al-Qurthubi, Muhammad ibn Ahmad. Tafsìr Al-Qurthubi, Vol. 9. Beirut: Dar alKutub al-'Ilmiyah, 2014.

Al-Qurțubī, Muhammad ibn Ahmad. Tafsìr Al-Qurțubī, Vol. 3. Beirut: Dar alKutub al-Ilmiah, 2014.

Al-Rāzī, Fakhruddin. Al-Tafsìr Al-Kabìr Aw Mafätỉh Al-Gayb, Vol. VIII. Cairo: Der el-Hadis, 2012.

- Al-Tafsìr Al-Kabìr Aw Mafätih Al-Gayb, Vol. VIII. Cairo: Dar al-Hadis, 2012.

Al-Sāwī, Abdullah Abelaziz Al-Muslih; Abdjawad. Al-I'jār. Al-Ilmī Fì Al-Qur'ān Wa Al-Sunnah. Jeddah: King Fahd al-Watani, 2008.

Al-Shāfi'̀', Hosen Muhammed Fahmi. Al-Dalìl Al-Mufahras Li Alfāz Al-Qur'ān. Cairo: Der el-Hadis, 2000.

Al-Shāṭibī, Ibrahim bin Musa. Al-Muwāafaqāt Fi Ushūl Al-Syariah. Beirut: Dar alKutub al-'Ilmiyyah, 2013.

Al-Shawkān̄̄, Muhammad bin Ali bin Muhammad. Fath Al-Qadir Al-Jāmi’ Baina Fannai Al-Riwayah Wa Al-Dirayah Min Tlm Al-Tafsir, Vol. 4. Beirut: Dar Ibnu Hazim, 2014.

—. Fath Al-Qadìr Al-Jämi' Baina Fannay Al-Riwāyah Wa Al-Dirāyah Min Tlm Al-Tafsir, Vol. 3. Beirut: Dar Ibnu Hazim, 2014.

Al-Shirbașī, Ahmad. Qișșat Al-Tafsìr. Cairo: Dar al-Qalam, 1962.

Al-Suyūṭ̄i, Jalāluddīn. Al-Itqān Fi 'Ulum Al-Qur'an, Vol. 2. Vol. 2. Beirut: Dar alKutub al-Ilmiah, 1996.

Al-Ṭabarī, Ibnu Jarir. Jāmi’ Al-Bayān Fi Ta'mūl Ay Al-Qur'ān. Vol. 12. Beirut: Dar al-Kutub al-Ilmiyah, 2009.

Al-Żahabī, Muhammad Husein. Al-Tafsìr Wa Al-Mufassirūn, Vol. 2. Cairo: Maktabah Wahbah, 1995.

Ferrara, L Aldo, A Sonia Raimondi, Lucia d'Episcopo, Lucio Guida, Antonio Dello Russo, and Teodoro Marotta. "Olive Oil and Reduced Need for Antihypertensive Medications." Archives of Internal Medicine 160, no. 6 (2000): 837-42. 
Hanafi, Muchlis. Tafsir Ilmi: Eksistensi Kehidupan Di Alam Semesta. Jakarta: Lajnah Penatashihan Mushaf Al-Qur'an Kementerian Agama RI, 2015.

Jansen, Johannes J G. The Interpretation of the Koran in Modern Egypt. Brill Archive, 1980.

Jauziyah, Ibnu Qayyim al-. Zad Al-Ma’ad Fi Hady Khair Al-Ibad. Beirut: Muassasat al-Risalat, 2009.

Johnson, J.M. Fructose. InEncyclopedia of Food Science, Food Technology and Nutrition. Edited by R. Macrae, R. K. Robinson, and M. Sadler. London: Academic Press Ltd, 1993.

Kathīr, Imaduddīn Ibnu. Tafsìr Al-Qur'ān Al-'Azìm. Beirut: Dar al-Kutub alIlmiah, 2000.

Kiritsakis, A, and P Markakis. "Olive Oil: A Review." Advances in Food Research 31 (1988): 453-82.

Laila, Izzatul. "Penafsiran Al-Qur'an Berbasis Ilmu Pengetahuan.” Epistemé: Jumal Pengembangan Ilmu Keislaman 9, no. 1 (2014): 45-66.

Linos, Athena, Virginia G Kaklamani, Evangelia Kaklamani, Yvonni Koumantaki, Ernestini Giziaki, Sotiris Papazoglou, and Christos S Mantzoros. "Dietary Factors in Relation to Rheumatoid Arthritis: A Role for Olive Oil and Cooked Vegetables?" The American Journal of Clinical Nutrition 70, no. 6 (1999): 1077-82.

Mubashir \& Mahran. Ghażà'Wa Al-Dawä' Fì Al-Qur'än Al-Karim. Cairo: Der elFikr, 2010.

Musbikin, Imam. Mutiara Al-Qur'an. Yogyakarta: Pustaka Pelajar, 2014.

Saleh, Sujiat Zubaidi. "Epistemologi Penafsiran Ilmiah Al-Qur'an.” TS $A Q A F A H$ 7, no. 1 (2011): 109-32.

Sanad, Hamudah Muhammad Dawud. "Al-I’jāz Al-'Ilmī Li Al-Qur'Ān Wa AlSunnah: Nazariyah Wa Al-Tațbīq." Kulliyat Al-Dirasat Al-Islamiyyah Wa AlArabiyah, Dubai Uni Emirat Arab 9 (1995): 83-114.

Shihab, M. Quraish. Membumikan Al-Qur'an. Bandung: Mizan, 1994.

- Tafsir Al-Misbab: Pesan, Kesan, Dan Keserasian Al-Qur'an, Vol. 15. Jakarta: Lentera Hati, 2005.

TTalbah, Hishām. Al-Ijā̃ Al-Ilmì Fì Al-Qur'ān Wa Al-Sunnah. Cairo: Der el-Hadis, 2011. 
438 | AL QUDS : Jurnal Studi Alquran dan Hadis vol. 5, no 2, 2021

Țayyāra, Nadia. Mawsū'ah Al-Ijjāz, Al-Qurāni Fü Al-Ulüm Wa Al-Tỉbb Wa Al-Falak. Abu Dabi: Maktabah Al-Shafa, 2009.

Umar, Nasaruddin. "Al-Qur'an Abadi Sepanjang Zaman." In Ensiklopedi Kemukjizatan Ilmiah Dalam Al-Qur'an Dan Sunnah. PT Kharisma Ilmu, 2008. 